\title{
Muusikalised arendusvõtted ja muusikalise mõõtme konstrueerimine Jaan Malini häälutustes
}

\author{
Kerri Kotta \\ Eesti Muusika- ja Teatriakadeemia muusikateooria professor \\ kerri.kotta@gmail.com
}

\begin{abstract}
Teesid: Jaan Malini häälutused asetsevad kirjandusvormina luule ja muusika piirimail. Käesolev artikkel keskendub Malini häälutuste lõikudele, kus teksti sidusus semantilisel tasandil asendatakse seda moodustavate sõnade sidususega kõla või rütmi tasandil. Sõnade või fraaside kõlalise või rütmilise sidususe saavutamiseks kasutab Malin muusikalisele arendusele omaseid võtteid: täpne või varieeritud kordamine, killustamine ja summeerimine, otsestel ja kaudsetel kõla assotsiatsioonidel põhinevad üleminekud (nn kõlalised "lingid"), kõlalised palindroomid (retrograadid), kõla järkjärguline transformeerimine, vormiline haakumine (overlap) ja vormilised interpolatsioonid. Lisaks eelnevale kirjeldatakse pendeldamist keelelise ja muusikalise dimensiooni vahel ka semantilise "hõrendamise" ja "tihendamise" mõistetes.
\end{abstract}

Märksõnad: häälutus, keel, muusika, muusikaline vorm, muusika vormilised arendusvõtted

\section{Sissejuhatus}

Kõlaluulet $^{1}$ (sound poetry) määratletakse luule iseloomuliku avaldumisvormina, mille puhul keskset rolli mängivad selle kui kunstilise kõne foneetilised ehk kõlalised aspektid. Kuigi kõlaline aspekt, s.t sõnade ja nende ühendite iseloomulik "rütm" ja "värv" on luules oluline ka üldisemalt, ehitatakse just kõlaluules mõtestatud tervik üles mitte niivõrd teksti semantilisest, kuivõrd kõlalisest sidususest lähtuvalt. Sellest aga tuleneb omakorda kõlaluule ja nn absoluutse muusika ${ }^{2}$ suur sarnasus "sisu" konstrueerimisel. Nii nagu muusikaski ei pruugi kõlaluuletuse "tähendus" või "mõte" kasvada välja kasutatud keeleüksuste semantikast, vaid pigem nende iseloomulikust kõlalisest vormist. ${ }^{3}$ Seega võib formaalesteetilise maksiimi "vorm on sisu, sisu on vorm" analoogiliselt muusikaga omistada teatava piirini ka arvukatele kõlaluulet esindavatele teostele. 
Kuna absoluutses muusikas konstrueeritakse teose tähendus suuresti struktuuri kaudu, siis tähendab sellise muusika mõistmine eelkõige selle vormi mõistmist, kus mõistet vorm tuleks tõlgendada üsna avaras tähenduses, teost moodustavate komponentide ja nende vaheliste suhete summana. Klassikaline normatiivne vormiõpetus ehk Formenlehre, nagu sellele sageli viidatakse, kujuneski 19. sajandil välja paralleelselt absoluutse muusika mõiste kasutuselevõtuga. Tegemist on ühtlasi nähtusega, mis kaasneb muusikaõpetuse institutsionaliseerumisega, konservatooriumite asutamisega Euroopas ja mõnevõrra hiljem ka mujal. Traditsioonina on see elav ka tänapäeval, kuna enamikes kõrgemates muusikakoolides loetav vormiõpetus põhineb ikka veel suuresti ajaloolise Formenlehre mudelitel.

Üks viimaseid suurejoonelisemaid katseid Formenlehre traditsiooni moderniseerida on seotud William Caplini ${ }^{4}$ nimega. William Caplin esindab Arnold Schönbergist ${ }^{5}$ alguse saanud koolkonda, mille õpetuse kohaselt mistahes vormilõigu otstarbe (funktsiooni) mingis suuremas vormilises tervikus määrab ära eelkõige selle ajaline paiknemine. Vormilõikude ajalise paiknemise (algus, keskpaik või lõpp) ja iseloomulike muusikaliste tunnuste põhjal kirjeldab Caplin rida erinevaid funktsioone, mida mingi vaadeldav lõik suuremas tervikus esindab. (Caplin 1998: 9-21)

Klassikalisele instrumentaalmuusikale omaselt esitatakse kõige olulisem materjal ehk vormilõik, millesse on kätketud peamine muusikaline idee, teose alguses. Seda vormilõiku nimetatakse peateemaks ehk nimetatud lõik on tervi$\mathrm{ku}$ seisukohast peateema funktsioonis. Peateema funktsiooni esindavale lõigule on iseloomulik range (tight-knit) ülesehitus. Peateema elementaarseimat vormi nimetab Caplin suureks lauseks (sentence). Standardne suur lause moodustub kaheksast taktist, mis jagunevad kaheks neljataktiliseks üksuseks: esituseks ehk esitavaks fraasiks (presentation phrase ehk presentation) ja jätkufraasiks (continuation phrase ehk continuation). Esitus jaguneb omakorda kahetaktiliseks tuumikfraasiks ehk tuumikuks (basic idea) ja selle täpseks või muudetud korduseks (repetition of basic idea) esindades ajalises mõttes peateema algust (beginning). Jätkufraas põimib endas peateema arenduse ja lõpetuse ehk temporaalses mõttes keskpaiga (middle) ja lõpu (end). Jätkufraasile iseloomulikult väljendub arendus sageli muusikalise materjali killustamises (fragmentation) ehk pikemate vormiliste liigendusüksuste järkjärgulises asendamises lühemate üksustega (näiteks $2+2+1+1+1 / 2+1 / 2$ jne, kus number tähistab kas taktide või löökide arvu), lõpetus aga n-ö summeerimises ehk killustamisele vastandlikus nähtuses, kus lühematele üksustele järgneb neid kokku võttev pikem üksus (näiteks 1+1+2). (Caplin 1998: 35-47) Suure lause jätkufraasi kontekstis nimetatakse sündmust, kus killustumine asendub summeerimisega, ka likvidatsiooniks, ning sellega kaasneb ühtlasi suurt lauset lõpetav harmooniline kadents, 
s.t klassikalise harmoonia seisukohalt konventsionaalse ülesehituse ja püsiva (stabiilse) harmooniaga lõppev akordijärgnevus. (Caplin 1998: 11, 43, 75, 131)

Näites 1 on ära toodud Beethoveni 5. sümfoonia I osa suure lause vormis peateema. Kuna peateemale eelneb ühtlasi seda sissejuhatav moto ehk põhimotiiv (taktid 1-5; ei kajastu näites 1), mis valitseb kogu I osa, siis algab peateema alates kuuendast taktist ${ }^{6}$ (taktinumbrid ehk väiksemad kursiivis numbrid on ära toodud taktijoonte kohal). Peateema hõlmab takte 6-21 ehk selle pikkus on 16 takti. Caplini sõnul on Beethoveni 5. sümfoonia I osa peateema näol tegemist endiselt standardse kaheksataktilise suure lausega, kuid üksus, mida siin tajutakse ühe taktina, on noteeritud kahena - sellest ka poole suurem taktide arv (Caplin 1998: 36-37).

Kuna motiiv, millel sümfoonia I osa põhineb, on jamb, s.t selle rõhk asub motiivi lõpus, siis alustatakse ka tuumikfraasi alla jäävate taktide lugemist alles seitsmendast taktist ehk taktist, mille esimesele löögile langeb motiivi kõige rõhulisem heli (analoogiline põhimõte kehtib ka sellele järgnevate vormiosade puhul). Seega moodustavad suure lause esituse taktid 7-14 ning jätkufraasi taktid 15-21 (vt näide 1). Esitus jaguneb omakorda tuumikfraasiks (taktid 7-10) ja selle muudetud korduseks (taktid 11-14). Jätkufraas algab killustamisega: esituse neljataktiliste üksuste (taktid 7-10 ja 11-14) asemel kõlab esmalt kaks kahetaktilist üksust (taktid 15-16 ja 17-18) ning seejärel kaks ühetaktilist üksust (taktid 19 ja 20). Seda väljendab ka teema hüpermeetriline struktuur, mida väljendavad klambrid ja kastikestes numbrid noodisüsteemi kohal. ${ }^{7}$

Taktis 21 saabuv üksus tähistab aga killustamise lõppu. Kuna nimetatud takt on tähistatud fermaadiga, siis kõlab see vahetult eelnevate taktidega (19 ja 20) võrreldes umbes poole pikemalt ${ }^{8}$ ning mõjub seetõttu eelnevaid takte summeeriva üksusena (takte 19-21 saab tajuda struktuurina $1+1+2$, milles numbrid 1+1 tähistavad takte 19 ja 20 ning number 2 fermaadiga takti 21 ; vt näide 1). Seega võib takti 21 puhul rääkida ühtlasi likvidatsioonist, mida artikuleerib ka teemat lõpetav harmooniline poolkadents. ${ }^{9}$

Kui vaadata muusikalist materjali, millel Beethoveni 5. sümfoonia I osa peateema põhineb, siis on näha, et see on üsna homogeenne. Sisuliselt kõik on tuletatud motiivist, mis koosneb kolmest kaheksandiknoodist . . . ja sellele järgnevast pikast rõhulisest noodist (tavaliselt pool- või veerandnoodist, vastavalt $\_$või •; seega avaldub motiiv tervikuna kas ... d või ....). Näiteks moodustub tuumikfraas nimetatud motiivi kolmekordsest läbiviimisest taktides 6-7, 7-8 ja 8-10 (vt näide 1). Viimasel läbiviimisel on motiivi lõpetavat nooti pikendatud kaks korda, mistõttu on ka motiiv tervikuna tavapärasest kaks korda pikem. Ühtlasi saab siin rääkida ka summeerivast struktuurist $1+1+2$, kus numbritele 1+1 vastavad taktid 7 ja 8 ning numbrile taktid 9-10. 

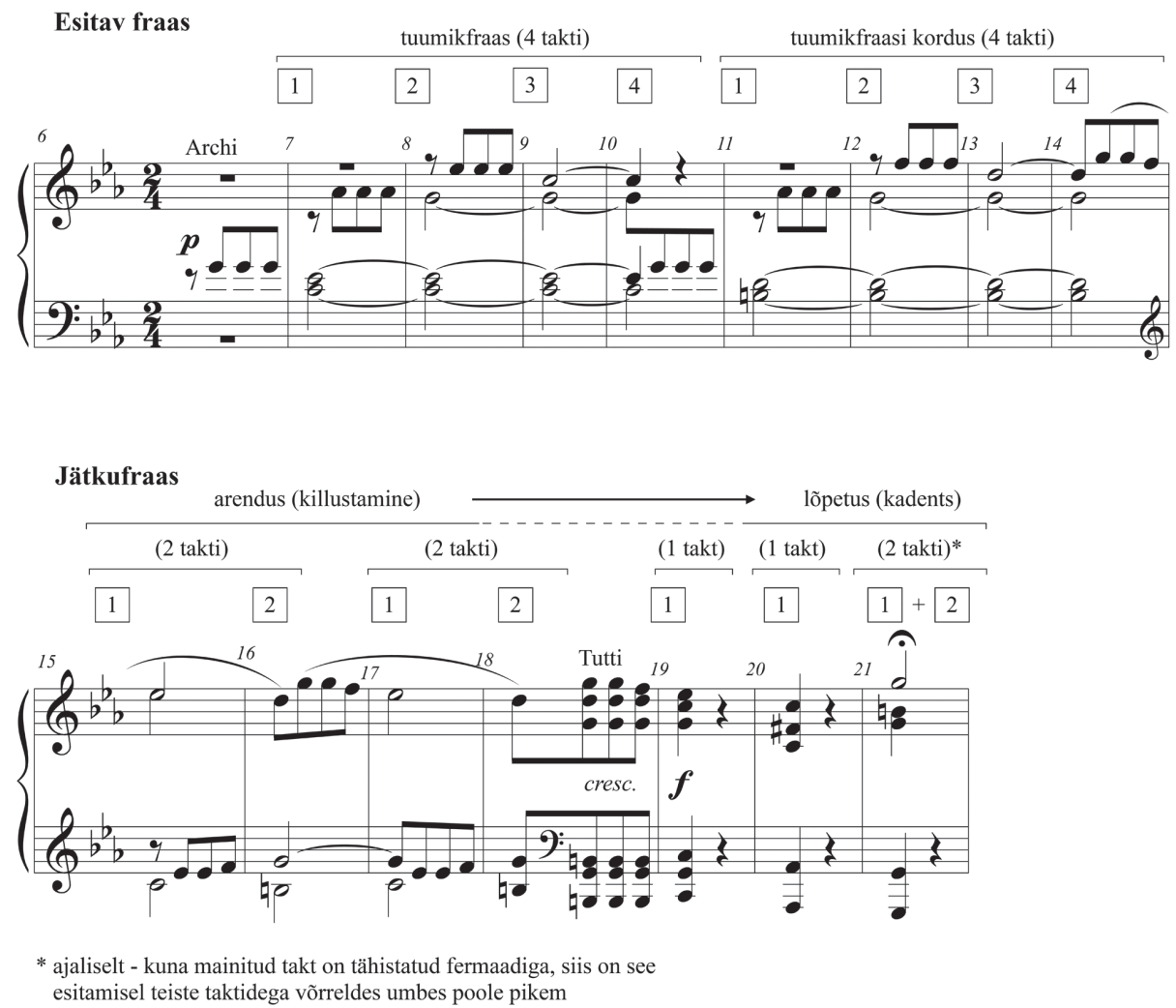

Näide 1. Suur lause Beethoveni 5. sümfoonia peateema vormina.

Analoogilise ülesehitusega on ka tuumikfraasi kordus, kus motiiv kõlab taktides 10-11, 11-12 ja 12-14. Alates killustamisest kõlab motiiv kaks korda vaheldumisi ülemises ja keskmises hääles (vt takte 14-15 ja 15-16 ning 16-17 ja 17-18) ning seejärel tervikuna kogu orkestri poolt esitatuna (vt tutti, taktid 18-19). Takte 20 ja 21 võib mõista sama motiivi osaliste kordustena, kus kõlab ainult motiivi lõpetav pikk noot (vt näide 1).

Eelpool kirjeldatu demonstreerib, et muusikalise narratiivi pidevus ja loogilisus saavutatakse suuresti korduste kaudu, mis võivad olla täpsed, kuid on sagedamini muudetud. Ühelt poolt saab korduvat motiivi suhestada hõlpsalt eelnevaga, teiselt poolt on selles tehtud väiksed muudatused tõlgendatavad arenguna. Järkjärgulised muudatused võivad motiivi teisendada kujule, mis erineb algsest kujust oluliselt ning on algse kujuga seostatav vaid konkreetse muusikalise arengu kontekstis (vrd nt takte 6-7 ja 20). Protsessi, milles motiiv või muusikaline materjal laiemalt omandab teisenemise käigus algkujuga võrreldes kontrastse või vastandliku ilmnemiskuju, nimetatakse transformatsiooniks. 


\section{Malini häälutuste muusikalisest analüüsist}

Mõistete kõlaluule ja kõlaline luule asemel kasutatakse eesti keeles sageli sõna häälutus, mis on Ilmar Laabani ${ }^{10}$ poolt pakutud vaste. Häälutusteni jõudis Laaban järkjärgult, sürrealistliku luule kaudu ${ }^{11}$, milles häälutustele omased elemendid - ootamatud kõlalised assotsiatsioonid ja üleminekud - mängivad samuti olulist rolli. Laabani konkreetse eeskujuna on mainitud ka Kurt Schwittersit, kelle "Ursonate" (Ürgsonaat) on saanud kõlaluule klassikaks. Huvi sedalaadi loomevormi vastu oli ühtlasi seotud Laabani haridusega: lisaks õpingutele Tartu ja Stockholmi ülikoolis õppis ta ka Tallinna Konservatooriumis (praegune Eesti Muusika- ja Teatriakadeemia) klaverit ja kompositsiooni, viimast Heino Elleri juures (Muru 2000).

Jaan Malin ${ }^{12}$ on kaasaegse eesti kirjanduse üks olulisemaid kõlaluule viljelejaid, kes jõudis nimetatud loomevormini suuresti Laabani kaudu, olles viimast uurinud ja tõlkinud. Üldiselt on juba luules, aga seda enam häälutustes sõnavariantide täis- ja kaashäälikulised muutused kõrvutatavad meloodiliste ja rütmiliste muutustega muusikas. Võib aga küsida, kas see on piisav, et kasutada Malini häälutuste analüüsimiseks niivõrd spetsiifilist lähenemist, nagu seda on muusika klassikaline vormianalüüs.

Esmapilgul seisavad klassikaliste muusikateoste suhteline vormiline rangus ja Malini häälutuste dadaistlik vaim teineteisest tõesti võrdlemisi kaugel. Lähtuvalt kõlaluule ja avangardmuusika sarnasest vabameelsest suhtumisest helisse, mille kohaselt on helina ehk esteetilist informatsiooni kandva kõlalise nähtusena käsitletav mistahes sellelaadne sündmus ${ }^{13}$, oleks Malini häälutusi ehk loomulikum võrrelda avangardmuusikast laenatud näidetega ${ }^{14}$. Selline käsitlus oleks kindlasti põhjendatud siis, kui uurimise all oleks Malini häälutuste kõlaline väljund. Siinses uurimuses proovitakse aga Malini häälutuste muusikalisi aspekte avada strukturaalselt, s.t häälutuste aluseks olevate tekstide ülesehituse kaudu. Teisisõnu proovitakse Malini tekste analüüsida muusikaliste tekstidena.

On see aga kõlaluule ja spetsiifilisemalt Malini puhul õigustatud? Missugusel määral sisalduvad häälutuste muusikalised kvaliteedid üldse häälutuste tekstides ja kas mainitud kvaliteete ei peaks siiski otsima peamiselt esitusest? Vähemalt Malini häälutuste puhul saab väita, et muusikalisi omadusi sisaldavad mõlemad. Malini kui esitaja väljendusvahendite rikkus ja karakteersus on märkimisväärne ning see kipub varjutama tõsiasja, et esitades peab Malin häälutuste tekstist võrdlemisi rangelt kinni: tekstide ja erinevate esituste võrdlemine võimaldab väita, et varieeruvus kirjapandu ja selle kõlalise resultaadi vahel ei ole kaugeltki nii suur, kui Malini värvikaid ettekandeid kuulates võiks eeldada. Seetõttu on Malini häälutustes teksti ja esituse suhe üsna sarnane klassikalisele muusikale, kus teksti erinev artikuleerimisviis on 
lubatud määrani, kus see ei hakka kahjustama teksti struktuuri. Erinevalt näiteks džässintepreedist, kes käsitleb seda, mis muusikast on kirja pandud, sageli vaid improvisatsiooni lähtena, kannab Malin oma teksti ette enamasti täiesti klassikalisel viisil. Malini häälutuste improvisatsioonilisus ja suhteline sõltumatus tekstist on seega suuresti näiline.

Viimane põhjendab järelikult seda, miks Malini häälutuste tekstid võivad olla iseseisva analüüsi objekt, kuid mitte seda, miks peaks Malini häälutusi võrdlema just klassikalise muusika repertuaariga - on ju kordamine ja varieerimine omane mistahes ajalisele kunstivormile üldisemalt. Siin on vaja teadvustada konteksti, milles nn muusikalised arendusvõtted esile tulevad. Näiteks regilaulus või muusikalises minimalismis on kordamine sageli maagilise tähendusega, selle eesmärgiks on teatava atmosfääri, tunde jne süvendamine. Klassikalise muusika vormilised struktuurid on aga teleoloogilised, mistõttu nende puhul tähendab kordamine alati ühtlasi liikumist mingi lõpplahenduse suunas. Kuigi Malini häälutustel on olemas ka n-ö maagiline kihistus, mängivad need vähemalt tekstidena sageli vastuvõtja ootustel, mida teksti loogiline ja sidus ülesehitus ka kergesti tekitab. Teisisõnu - kordused, tekstirütmi killustamine ja summeerimine ning kõlaline transformatsioon ei avaldu Malini häälutustes lihtsalt neutraalsete, vaid analoogiliselt klassikalise muusikaga eelkõige eesmärgistatud liikumist tähistavate võtetena. Seega on Malini häälutuste võrdlemine klassikaliste muusikateostega vähemalt teatava piirini õigustatud. Samas tuleb teadvustada, et allpool toodud võrdlused ja analüüs ei ava Malini häälutuste muusikalisi külgi kogu rikkuses, vaid eelkõige osas, mis puudutab häälutuste aluseks oleva teksti kõlalise pidevuse ja kõlalise seotuse saavutamist.

\section{Analüüs}

Nii nagu muusikas, on ka Malini häälutustes üheks kõige tavalisemaks võtteks kordamine. Näiteks häälutuses "Sääl, kus Läänemere...” töötleb Malin tuntud rahvalikku laulu. Põhiliseks vormiliseks võtteks on originaalteksti sõnadesse "takerdumine", kus sõnale järgneb rida selle foneetilisi variante, millest ainult mõned on vaadeldavad kindlat tähendust omava sõnana (vt näide 2a). Malini häälutuse alguses kasutatud arendusvõtet saab puhtformaalselt võrrelda Beethoveni 17. klaverisonaadi d-moll III osaga, mille alguses kõlab lühike ühetaktiline motiiv ja rida selle variante (näites $2 \mathrm{~b}$ on need tähistatud süsteemide kohal kui a, $a_{1}, a_{2}$ ja $a_{3}$ ). Motiivi erinevad variandid põhinevad kõik ühesugusel rütmil, mille analoogiks Malini häälutuse puhul on korratava sõna silpide arv. Erinevaks muudab motiivid aga eelkõige harmoonia ja väiksed muutused meloodilises ülesehituses, mille vasteks Malini häälutuses on eelkõige korratavate sõnavariantide täis- ja kaashäälikulised muutused. 
$\mathbf{A}$

Sääl, kus
mus
kas
tos
ses

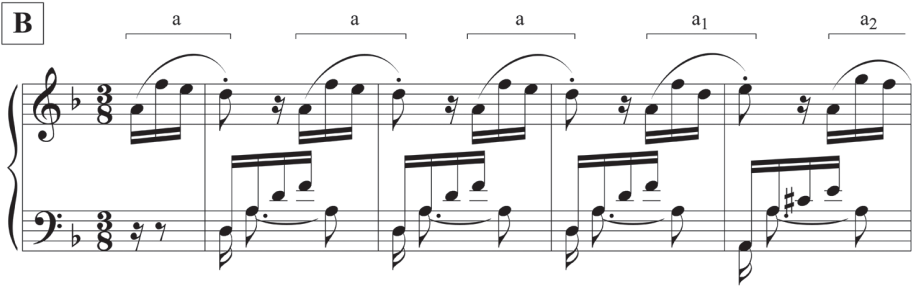

Lääne

sääne

vääne

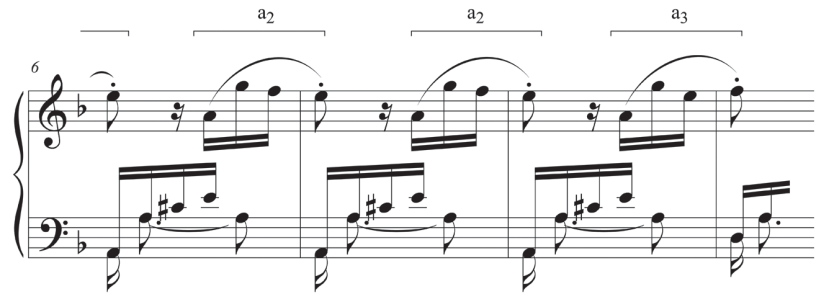

Näide 2. Kordamine Malini häälutuse “Sääl, kus Läänemere...” ja Beethoveni klaverisonaadi $n r .17$ d-moll III osa alguses.

Analoogiliselt muusikaga võib korratav üksus olla ka pikem. Näites 3a on toodud katkendid Malini häälutuse "Welcome to Estonia" tekstist ja näites 3b Bachi süidi soolotšellole G-duur prelüüdi algus. Sarnaselt näitele 2 põhinevad ka siin kõik Bachi teose aluseks oleva motiivi variandid (tähistatud näites 3b kui a, $\mathrm{a}_{1}, \mathrm{a}_{2}$ ja $\mathrm{a}_{3}$ ) ühesugusel rütmil, kuid erineval harmoonial; konstantsele rütmile vastaks Malini häälutuses taas korratavate fraaside silpide arv, teisenevale harmooniale aga fraaside häälikulised muutused.

A

angumata anu otsa tangumata tanu otsa sangumata sanu otsa

nigu nii $\rightarrow$ nigu naa vigu vii $\rightarrow$ vigu vaa rigu rii $\rightarrow$ rigu raa tigu tii $\rightarrow$ tigu taa

samasse ehk samma lamasse ehk lamma jamasse ehk jamma komasse ehk komma
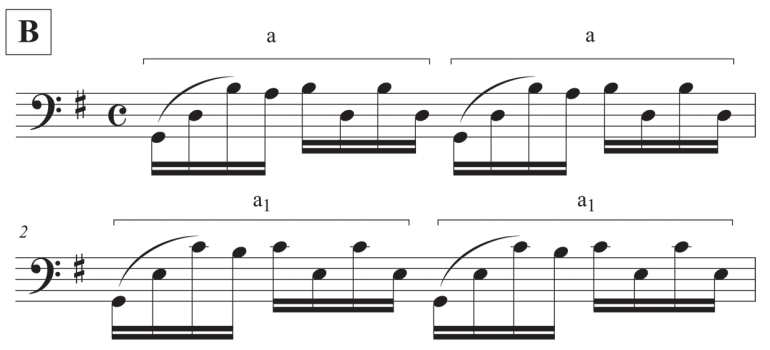

$\mathrm{a}_{2}$

$\mathrm{a}_{2}$

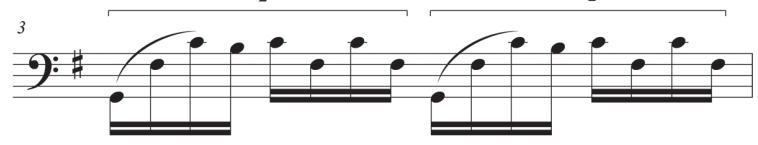

$\mathrm{a}_{3}$

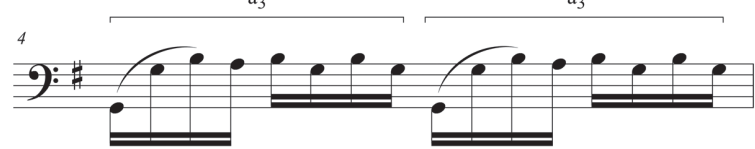

Näide 3. Kordamine Malini häälutuses "Welcome to Estonia” ja Bachi süidi soolotšellole G-duur, BWV 1007, prelüüdis. 
Kordamine võib olla ka rütmiliselt muudetud ehk tihendatud. Näites 4a on toodud Mozarti klaverisonaadi nr. 12 F-duur II osa kaks esimest takti. Teist takti (motiiv $a_{1}$ ) võib mõista kui esimese takti (motiiv a) transponeeritud ja rütmiliselt muudetud kordust. Rütmiline muutus on seotud motiivi a alustava veerandnoodiga • , mis motiivis $\mathrm{a}_{1}$ on asendatud punkteeritud rütmifiguuriga •. Näites 4 b on toodud katkend Malini häälutusest "Welcome to Estonia" ja näites 4c selle võimalik rütmistus. Esimese kahe rea silpide arv on võrdne. Kolmandas reas lisandub üks silp, kui esimese ja teise rea algussõnad "on" ja "son" asendatakse sõnaühendiga "bon-bon" (vt näide 4b), mille esimene "bon" on rütmiseeritud näite $4 \mathrm{c}$ teise rea viimase kaheksandikuna, mis funktsioneerib järgneva rea suhtes eeltaktina. Viimases reas on esimese ja viimase sõna algusesse lisatud täiendav, n-ö kogelemisefekti edasi andev kaashäälik, mida on võimalik rütmiseerida näiteks eellöögiga (vt näide 4c). Hoolimata kolmandas ja neljandas reas tehtud rütmilistest muutustest võib öelda, et korratava üksuse (rea) rütmiline põhistruktuur ei muutu; sama võib väita ka Mozarti klaverisonaadi teise takti kui esimese takti variandi kohta.
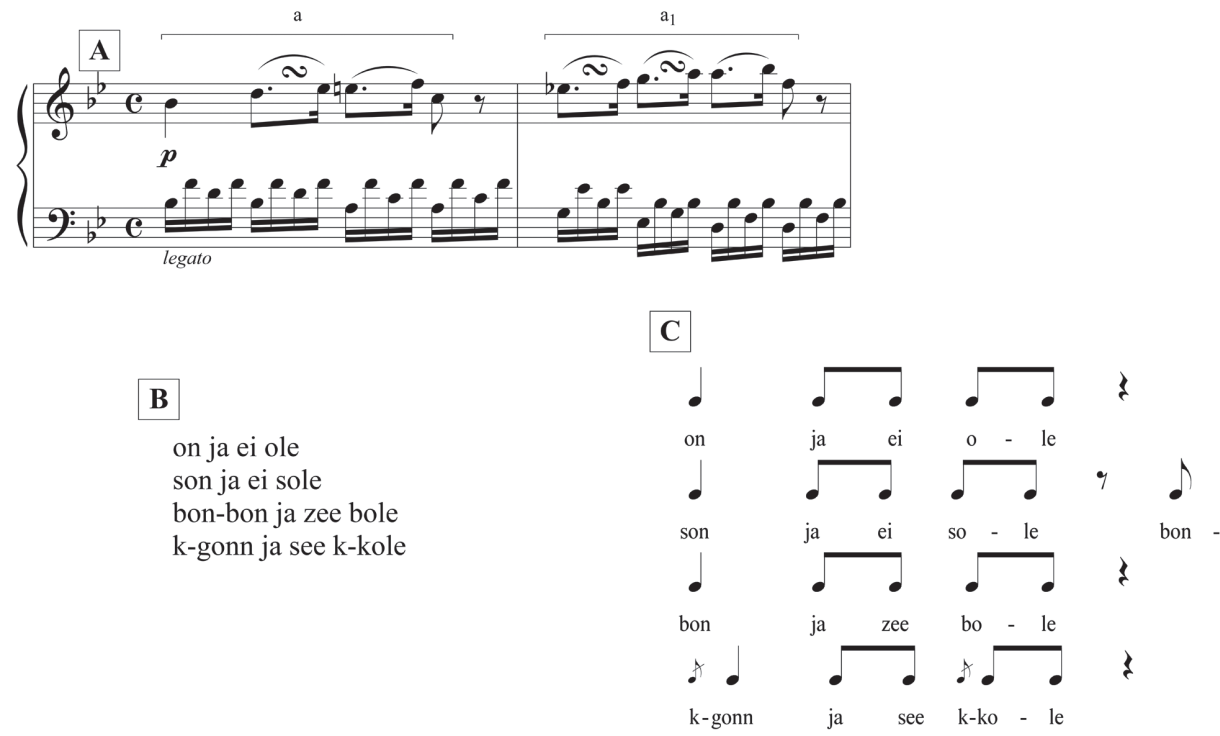

Näide 4. Rütmiliselt muudetud kordamine Malini häälutuses "Welcome to Estonia" ja Mozarti klaverisonaadi nr. 12 F-duur II osas.

Teisalt võib mõni Malini häälutuse aluseks olev tekstilõik imiteerida meetriliselt ka otseselt struktuuri, millel põhineb muusikaline suur lause (vt näide 5). Näites 5a (vasakul ülal) on toodud katkend häälutusest "Ma-zö-zu-ää" ja näites $5 \mathrm{~b}$ (paremal ülal) selle võimalik rütmistus. Kui käsitleda meetrilise üksuse- 
na sõna, siis ilmneb, et mainitud tekstilõik liigendub esmalt kaheks ühe takti pikkuseks üksuseks (“töö-tö-tö-tö-tööö” ja "nöö-nö-nö-nö-nööö”) ning seejärel kaheks poole takti pikkuseks üksuseks ("komplimento" ja "supramento"). Sellele järgneb kaks kaheksandiktakti pikkust üksust ("Vas" ja "ist") ning seejärel üks veerandtakti pikkune üksus (“das”). Kogu katkendi lõpetab poole takti pikkune üksus (“ÖÖÖ”). Mainitud meetrilise struktuuri sarnasus suure lausega avaldub esmalt seda alustavas kahes pikemas üksuses, mida võib tinglikult käsitleda tuumiku ja selle kordusena. Mõlemad üksused koos on ühtlasi vaadeldavad esitusena (vt näite 5b ülemist rida). Suurele lausele omaselt algab vaadeldava lõigu teine pool killustamisega - ühe takti pikkused üksused asendatakse esmalt poole ja siis kaheksandiktakti pikkuste üksustega -, millele järgneb omakorda summeerimine ehk n-ö likvidatsioon - kaheksandiktakti hõlmavatele üksustele järgneb veerandtakti ja seejärel poolt takti hõlmav üksus (vt näite $5 \mathrm{~b}$ teist rida). Seetõttu võib vaadeldava tekstilõigu teist poolt seostada suure lause jätkufraasiga. Tekstirütmi ja Beethoveni 5. sümfoonia I osa peateema rütmiline sarnasus võimaldab Malini teksti ka sümfoonia peateemale otseselt projitseerida (vt näide 5c; Malini tekst on kirjutatud noodisüsteemi alla).
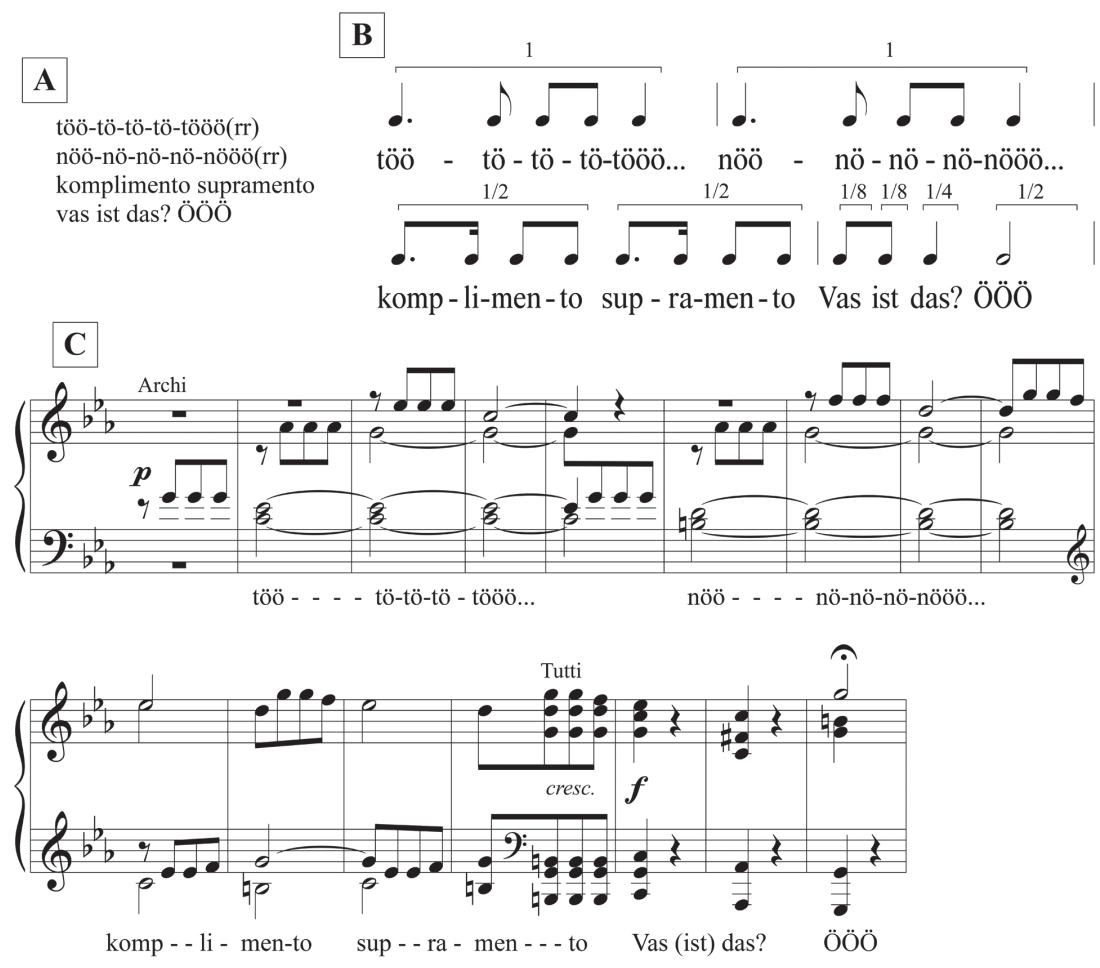

Näide 5. Suure lause meetriline struktuur Malini häälutuses “Ma-zö-zu-ää” ja Beethoveni 5. sümfoonia I osa suure lause vormis peateema. 
Muusikateoses kasutatakse kõlalisi (motiivilisi) assotsatsioone ka suuremate vormiosade ühendamiseks. Näiteks juba mainitud Beethoveni 5. sümfoonia I osa peateemale järgneva sidepartii alguses kõlab taas variant motiivist, mis valitseb peateemat tervikuna (vt näide 6). Näites 6a on ära toodud juba tuttav Beethoveni 5. sümfoonia I osa peateema, mis lõppeb taktis 21 (taktinumbrid on ära toodud vastavate taktide kohal). Peateemat valitseva motiivi variandid on ümbritsetud ellipsitega, mida ühendavad punktiirkaarega nooled. Viimast korda kõlab motiiv kogu orkestri esituses taktides 18-19. Ka järgneva sidepartii alguses (taktid 22-24) kõlab motiiv kogu orkestri esituses, mis seostab sidepartii alguse n-ö lokaalsel tasandil otseselt lõppenud peapartiiga (üldisemal tasandil seostab sidepartiid alustav motiiv ka taktides 1-6 kõlanud motoga, mis aga antud näites ei kajastu).

Analoogilisi kõlalisi seoseid (kõlalisi "linke") võib leida ka Malini häälutustes ühe suurema lõigu üleminekul teiseks. Näites $6 \mathrm{~b}$ on toodud katkend häälutusest "Welcome to Estonia". Kahte alaosa eraldab siin n-ö vormiline interpolatsioon ehk kiilund ("kamoon!", vt ka näidet 9), mis on kõlaliselt seotud nii eelneva kui ka järgneva lõiguga. Eriti selge on seos järgneva lõigu algusreaga, mida artikuleeriv "oon-oon-oon" kordab otseselt kiilundina funktsioneeriva sõna "kamoon" teist poolt. Näites $6 c$ on toodud katkend sama häälutuse lõpulõikudest. Ka siin seotakse esimese lõigu lõpp kõlaliselt mitmes plaanis järgneva lõigu algusega. Esmalt algab järgnev lõik sama täishäälikuga, kuid veelgi ilmsemaks muudab kõlalise seose järgneva lõigu teine sõna ("olegi”), mille kaks esimest vokaali langevad kokku esimest lõiku lõpetava sõna ("kkole”) vokaalidega. Kaudsemalt ja mõneti vaieldavamalt võib analoogilist kõlalist seost näha ka teise lõigu lõpurea algussõnade (“ega olegi”) ja kogu häälutust lõpetava hüüatuse algussõna ("Welcome") vahel (vt näide 6c).

Eelpool oli juttu transformatsioonist ehk siis motiivi teisenemisest määrani, kus selle vahetu seos oma algkujuga pole enam otseselt tajutav. Samas on seos tuvastatav konteksti kaudu, s.t et esmapilgul uus materjal on sellele eelneva materjali valguses tõlgendatav viimase (tugevalt teisenenud) avaldumiskujuna. Ka Malini häälutused sisaldavad lõike, kus üht laadi kõlarütm teisendatakse teistlaadi kõlarütmiks. Juba korduvalt viidatud häälutuses "Welcome to Estonia" ühendatakse üks lõik teisega sujuvalt ehk materjali järkjärgulise transformeerimise kaudu (vt näide 7). Näide 7a esitab häälutuse vastava lõigu, mis sisaldab transformatsiooni. Transformatsiooniala on ümbritsetud punktiirjoonega. Näide 7b illustreerib seda lähemalt, näidates, kuidas kõlarütmilisest üksusest (sõnast) "sangumata" saab eelviimase silbi äravõtmise ja alguskonsonandi muutmise teel "vanguta" ning viimasest lõpusilbi asendamise kaudu omakorda "vannnnGu-Gi”. Edasi muutuvad lisatud lõpusilbid omakorda n-ö uue kõlarütmilise üksuse tüveks "gu-gi”, mille vokaalne retrograad (järjestus u-i muutub järjestuseks i-u) saab aluseks järgmise rea sõnaalgusele "gilu-". 


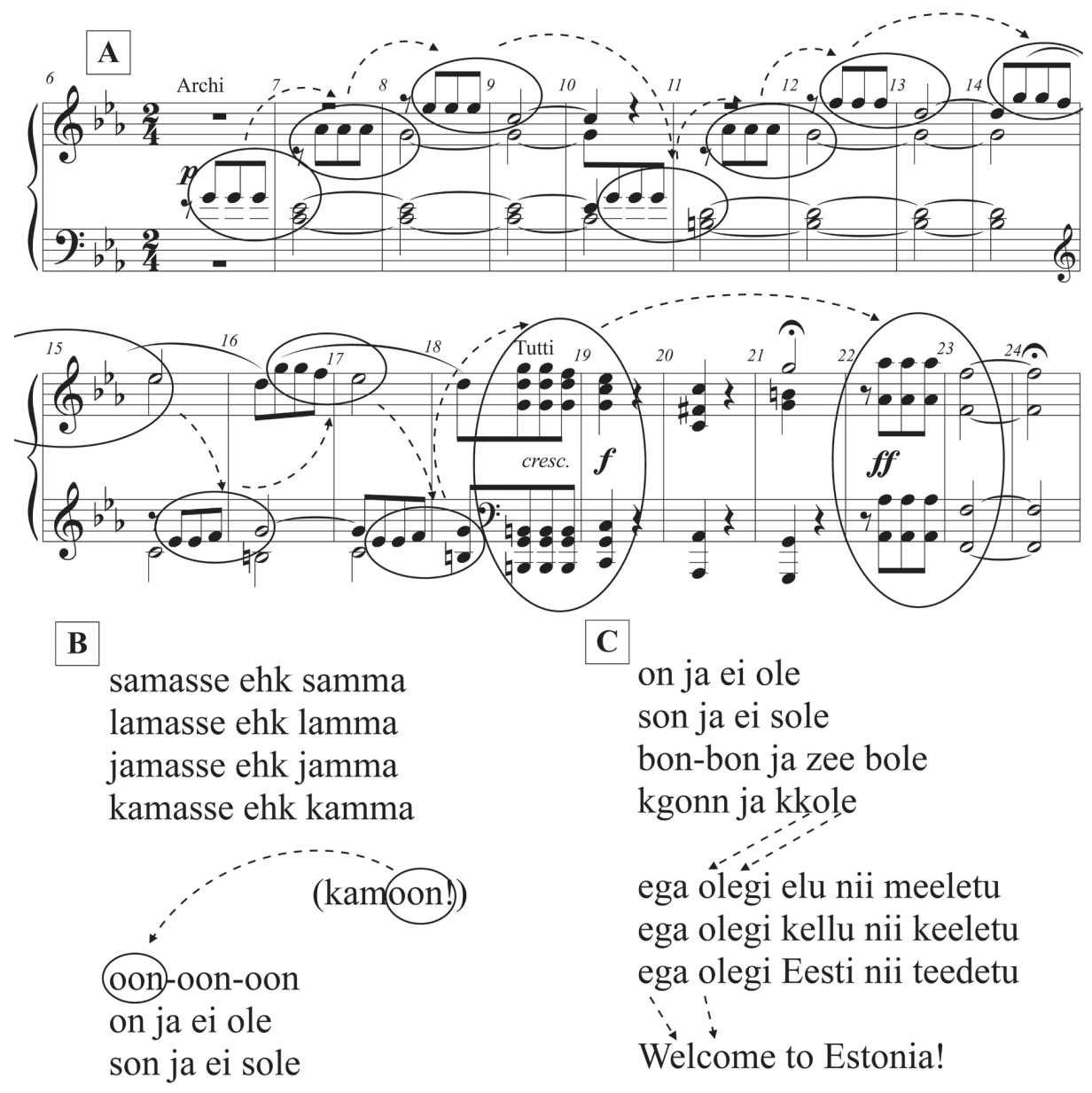

Näide 6. Kõlalised "lingid” häälutuses "Welcome to Estonia".

Üks võrdlemisi levinud vormilisi võtteid muusikas on kattumine (overlap). Sisuliselt on tegemist meetrilise nihkega, kus meetrumi nõrk osa mõtestatakse ümber tugevaks osaks. Näites 8a on toodud Mozarti 1. klaverisonaadi I osa peateema lõpp ja sellele järgnev sidepartii algus, mis algselt funktsioneerib peateemale järgneva täiendina (toonika orelipunktina), kuid mõtestatakse edasise arengu käigus ümber põhihelistiku toonikat hülgavaks sidepartiiks (nimetatud osa sidepartiist näites $8 \mathrm{a}$ ei kajastu). Peateema viimane hüpertakt hõlmab takte 11-12 ning selle löögid 1, 2, 3 ja 4 on tähistatud kastikestes numbritega noodisüsteemi kohal. Hüpertakti seisukohast on löögid 1 ja 3 rõhulised ehk tugevad ning 2 ja 4 rõhutud ehk nõrgad (analoogiliselt 
A

angumata anu otsa

tangumata tanu otsa

sangumata sanu otsa

vannguta...vannnng

Gu-Gi...gu-gi

gilulinn

nilulinn

ilulinn

vilu linn

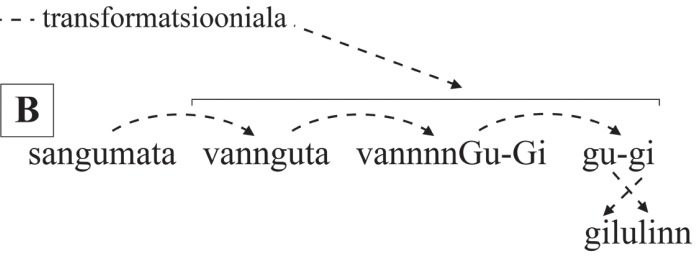

Näide 7. Transformatsioon häälutuses "Welcome to Estonia".

tavapärasele $4 / 4$ taktimõõdule, kus löögid 1 ja 3 on samuti rõhulised ning löögid 2 ja 4 rõhutud). Nimetatud hüpertakti viimase löögi (4) saabudes toimub muusikas faktuuri- ja karakterimuutus, mille tulemusena hüpertakti 4. löök mõtestatakse ümber uue hüpertakti 1. löögiks, sest uuest muusikalise materjali organisatsioonist tulenevalt on takti 12 teine pool tajutav uue vormilõigu algusena. Ühtlasi on selle tulemuseks meetriline nihe, mis tekib tajutava taktimõõdu ja nn reaalse ehk kirja pandud taktimõõdu vahel: uute hüpertaktide kõige rõhulisem osa ehk esimene löök langeb reaalse takti keskele ja mitte enam ootuspäraselt selle algusesse.

Sarnast nähtust võib täheldada ka ühe lõigu üleminekul teiseks häälutuses "Ma-zö-zu-ää". Näites 8b on toodud vastava katkendi tekst ning näites 8c on selle esimene pool rütmiseeritud. Ühtlasi on näite $8 \mathrm{c}$ noodisüsteemide kohale kirjutatud löögid analoogiliselt hüpertaktide löökidele Mozarti klaverisonaadis. Näitest 8c ilmneb, et teine rida on võrreldes esimese reaga ühe löögi võrra lühem. Samas riimub kolmanda rea esimene silp (sõna) esimese rea viimase silbiga, mis tähendab, et see võib skandeerimisel olla esmalt tajutav mitte niivõrd kolmanda rea alguse, kuivõrd teise rea lõpetusena (vt näide 8c). Järgneva teksti ülesehituse valguses mõtestatakse nimetatud silp muidugi meetriliselt ümber kui kolmanda rea algussilp (vt näite $8 \mathrm{~b}$ kahte viimast rida). Kõige selle tulemusena võib ka kõne all oleva häälutuse puhul rääkida meetrilisest kattumisest ehk ümbermõtestamisest, kus silbil (sõnal) on topeltfunktsioon: olla nii lõpetus kui ka algus. Samasugune topeltfunktsioon on ka Mozarti klaverisonaadi peateemat lõpetaval harmoonial (toonika) 12. takti teises pooles (vt näide 8a). 


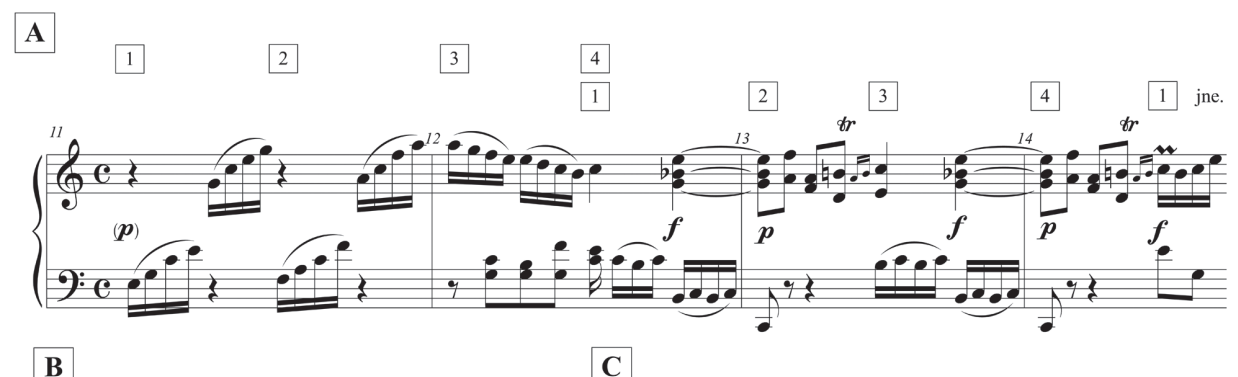

$$
\begin{aligned}
& \text { ÖÖ ölgö limbõ nöör } \\
& \text { ööhõ kambõ nimbõ. } \\
& \text { töö-tö-tö-tö-tööö(rr) } \\
& \text { nöö-nö-nö-nö-nööö(rr) } \\
& \text {... }
\end{aligned}
$$

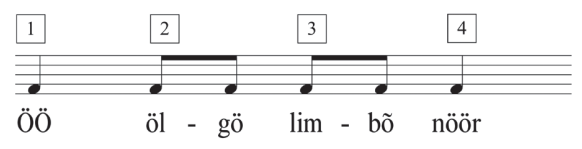

Näide 8. Kattumine Mozarti 1. klaverisonaadi C-duur I osas ja Malini häälutuses

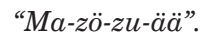

Eespool oli juba juttu interpolatsioonist ehk kiilundist (vt näidet 6 ja selle selgitust). Interpolatsiooniks nimetatakse muusikas lõiku, mis põhineb eelnevaga võrreldes uuel ja suhteliselt kontrastsel materjalil ning mis pole otseselt käsitletav eelneva muusikalise arengu tulemina, vaid pigem sellesse sekkumisena. Sellisena katkestab interpolatsioon ühtlasi muusikalise arengu pidevuse ning on põhidramaturgia seisukohalt vaadeldav omalaadse narratiivse tsesuuri ehk peatusena. Interpolatsiooni omaduseks on see, et selle eemaldamine muusikast ei lõhu viimase põhidramaturgiat (loogilist pidevust) ega vormistruktuuri.

Näites 9a on toodud Mozarti 1. klaverisonaadi III osa peateema. Erinevalt eelpool käsitletud peateemadest põhineb see suurest lausest mõnevõrra keerukamal struktuuril, mida muusika vormianalüüsis nimetatakse perioodiks (period). Periood koosneb kahest lausest - eellausest (antecedent phrase) ja järellausest (consequent phrase), mis mõlemad lõppevad kadentsiga: eellause poolkadentsi ning järellause täiskadentsiga. Mõlemad laused põhinevad reeglina sarnasel muusikalisel materjalil, mistõttu neid võib vaadelda kahe paralleelse protsessina, millest esimene jääb seda lõpetava poolkadentsi tõttu lahtiseks, teine on aga lõpetatud (vt ka joonealust märkust 9). Nii eel- kui ka järellause moodustuvad tuumikust (basic idea) ning sellega suhteliselt kontrastsest ideest (contrasting idea). Järellause kontraste idee võib olla eellause 
kontrastse idee uus variant või täiesti uus idee. (Caplin 1998: 49-58; konkreetse peateema analüüs on toodud Caplini raamatu näites 4.13, lk 56.)

Näites 9a on eellause toodud ülemises ja järellause alumises noodisüsteemis (vastavalt taktid 1-4 ja 5-10). Eellause tuumiku moodustavad taktid 1-2 ning sellele järgneva kontrastse idee taktid 3-4. Järellauses kui paralleelstruktuuris kõlavad need vastavalt taktides 5-6 ja 9-10. Põhjuseks, miks järellause kontrastne idee ei kõla ootuspäraselt taktides 7-8, on interpolatsioon, uus ja suhteliselt kontrastne materjal, mille eemaldamine taastaks konventsionaalse kaheksataktilise perioodi.

Näites 9b on toodud katke Malini häälutusest "Läksin mina Turku". Vastava katkendi struktuuriliseks teljeks võib pidada järjestikkusi hüüatusi "NII", "NAA", "NUU" jne. Peale kolmandat hüüatust "NUU" on sellele sulgudes lisatud justkui mingile avastusele või mõttele tulles täiendav hüüatus "ha!nnuu!", mis viitab häälutuse adressaadile: häälutus on pühendatud soome tõlkijale Hannu Oittinenile. Nimetatud hüüatust võib samuti käsitleda interpolatsioonina, sest nagu muusikaline interpolatsioon, on ka see tõlgendatav n-ö sekkumisena, mille tagajärjeks on põhistruktuuri loodud pidevuse katkestus. Malini häälutuste

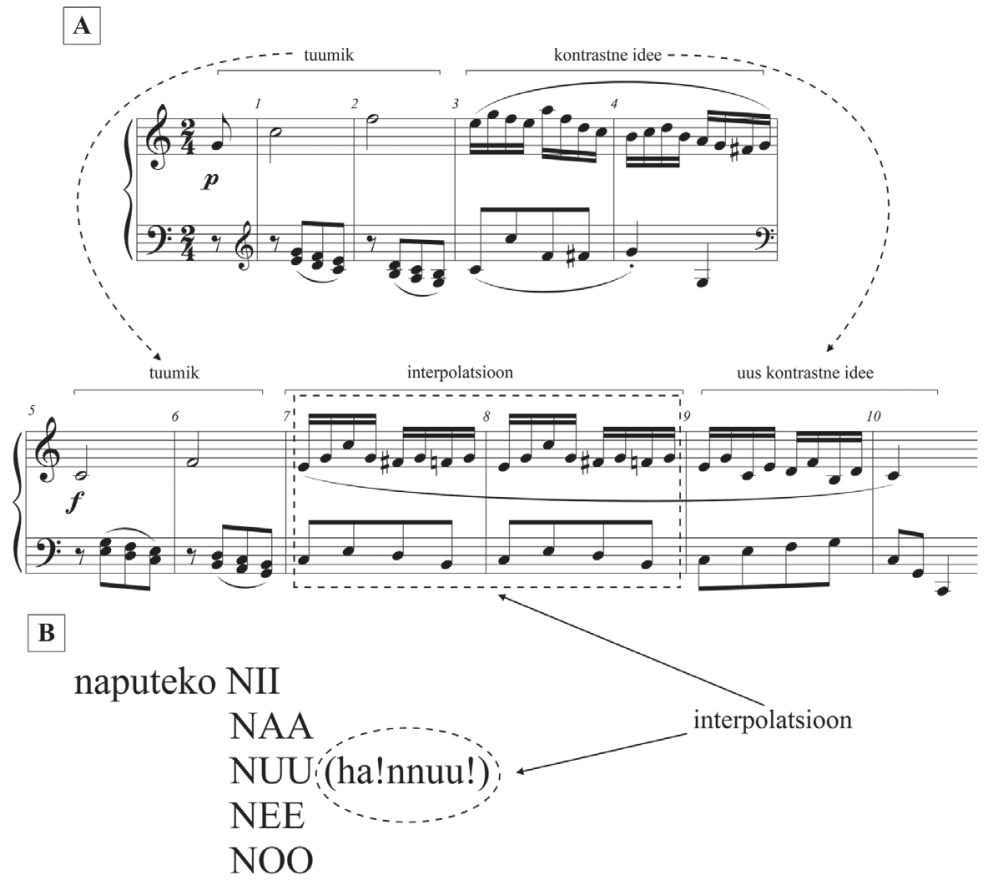

Näide 9. Interpolatsioon Mozarti 1. klaverisonaadi C-duur III osas ja Malini häälutuses "Läksin mina Turku”. 
interpolatsioone iseloomustabki tavaliselt järsk positsioonimuutus, autori kui isiku ja selle suhtumise jõuline sissetung keelemängu (vrd siin kirjeldatud interpolatsiooni ka kiilunditega "kamoon!" näites 6 ja “vicious" näites 10).

Interpolatsioon Malini häälutustes on omakorda seotud nähtusega, millele võib viidata kui sõna tähenduslikule nihkele või semantilise tasandi sissetungile. Tavaliselt ongi see seotud mingi sõnaliite või konstrueeritud sõnavormi assotsiatiivse seostamisega konkreetset tähendust omava sõna või pärisnimega. Näiteks “kamoon!" kui autori personaalne reaktsioon sõnale vahetult eelnenud keelemängule omab omakorda n-ö algriimilist kõlalist seost vahetult eelneva sõnaga "kamma" (vt näide 6). Veelgi tugevam on tähendusliku tasandi sissetung näites 9 kirjeldatud interpolatsiooni "ha!nnuu!" puhul, kus ebamäärase tähendusväljaga sõnavormile "NUU” järgneb konkreetne viide pärisnimele (vt näide 9). Liite assotsiatiivset seostamist pärisnimega kasutatakse ka häälutuses “Sääl, kus Läänemere...", kus sõnaliide "sid” teisendatakse sellele järgneva kommenteeriva interpolatsiooni kaudu kuulsa punkansambli "Sex Pistols" solisti nimeks (Sid Vicious, vt näide 10).

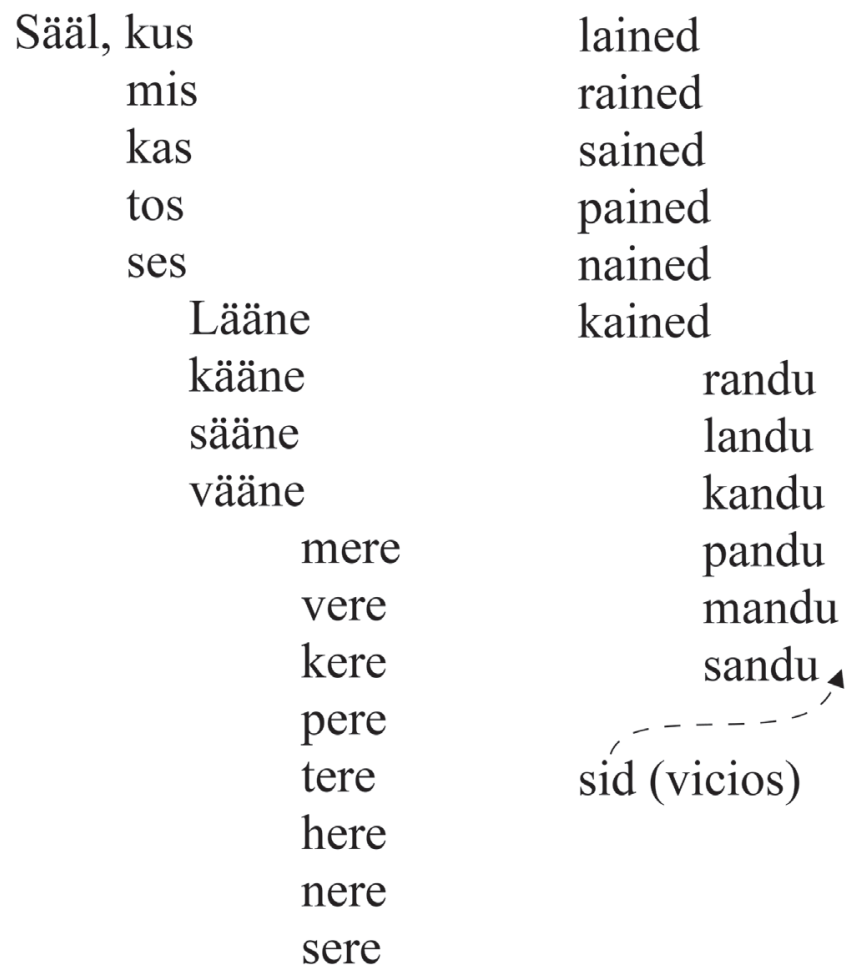

Näide 10. Sõnaliite teisendamine pärisnimeks Malini häälutuses “Sääl, kus Läänemere...”. 
Eelmises näites kirjeldatud sõna tähendusliku nihke puhul saab ühtlasi rääkida ka keelelisse või muusikalisse dimensiooni sisenemise strateegiatest. Keelelise dimensiooni all peetakse siin kõige üldisemalt silmas teksti semantilist ning muusikalise dimensiooni all selle kõlalist sidusust. Malini häälutuste puhul ei ole tegemist pelgalt muusikas kasutatavate arendusvõtete ülekandmisega keelde, vaid pigem nende rakendamisega keelelisest dimensioonist väljumiseks. Teisisõnu pendeldavad Malini häälutused pidevalt muusika ja keele piirimail ning kuigi konkreetsel juhul on võimalik öelda, kas valitseb muusikaline või keeleline dimensioon, ei ole ühe dimensiooni domineerimine kunagi täielik.

Ühest dimensioonist teise liikumist võib keele positsioonilt mõista ka semantilise "hõrendamise" või "tihendamisena". Näites 11 on toodud juba tuttava häälutuse "Sääl, kus Läänemere..." algus. Nagu juba öeldud, põhineb häälutus populaarse rahvaliku laulu teksti sõnade kõlalistel variantidel, mis järgnevad igale originaalteksti sõnale. Mõned neist on konkreetse tähendusega sõnad, mõned konkreetsele sõnadele viitavad vormid ning mõned originaalsõna tähendusetud kõlalised ekvivalendid. Kahte viimati nimetatud gruppi kuuluvad vormid on näites 11 ümbritsetud punktiirjoontega. Teise grupi puhul on vormi juurde kirjutatud ka sulgudes võimalik sõna, millele vorm potentsiaalselt viitab. Liikumist tähenduslikult sõnalt mingile sõnale viitavale vormile ning sealt

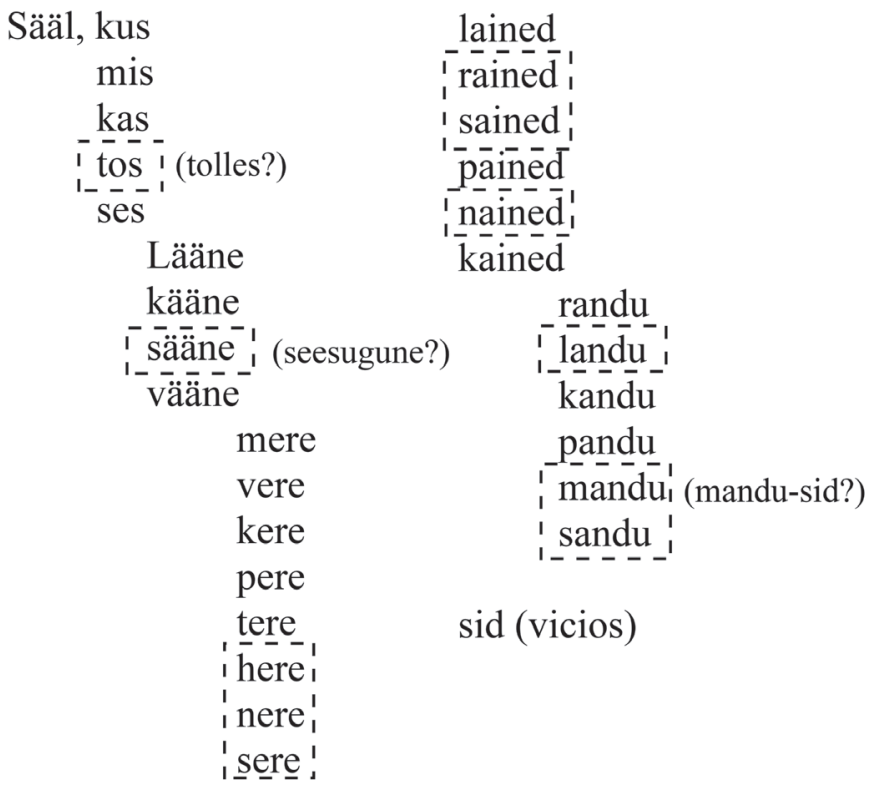

Näide 11. Semantiline "hõrendamine” Malini häälutuses "Sääl, kus Läänemere...”. 
edasi sõna kõlalisele ekvivalendile käsitletaksegi siin semantilise "hõrendamise" ehk muusikalisse dimensiooni sisenemisena, sest sedalaadi liikumises semantilise aspekti tähtsus väheneb ja kõlalise aspekti tähtsus teksti sidususe loomisel kasvab.

Vastupidine nähtus oleks seega mõistetav kui semantiline "tihendamine". Viimane võib jätkuda ka siis, kui semantiline sidusus on saavutanud maksimumi. Konkreetselt tähendab see mingile kindlat tähendust omavale sõnale kõlalise ekvivalendi järgnemist, mille informatiivne tihedus on mainitud sõnast suurem: näiteks asendatakse üks sõna kahe sõna või lausa arendatuma fraasiga. Näites 12 on toodud katkend häälutusest "Welcome to Estonia". Kuigi katkendi esimest sõnavormi "gilulinn" võib seostada sõnaga "kilulinn", mistõttu nimetatud vormi semantiline tihedus on sellele järgneva vormi "nilulinn" tihedusest suurem ning seega on esimeselt vormilt teisele üleminekule tegemist semantiline "hõrenemisega", võib kogu katkendid tervikuna vaadelda pigem semantilise "tihenemisena". Vormile "nilulinn" järgnev "ilulinn" omab erinevalt eelnevast konkreetset tähendust. Sellele omakorda järgnevad "vilu linn" ja "silu, linn" on aga informatiivses mõttes veelgi "tihedamad“, esimene omadussõnalise epiteedi "vilu" ning teine käsksõna "silu" lisamise tõttu. Kuhjuvast informatiivsusest tulenev pinge vallandub katkendi viimase rea silpide arvu plahvatuslikus kasvus ehk semantilise "tiheduse" normaliseerumises (s.t olukorras, kus igal kõlalisel üksusel on taas enam-vähem võrdne semantiline kaal).

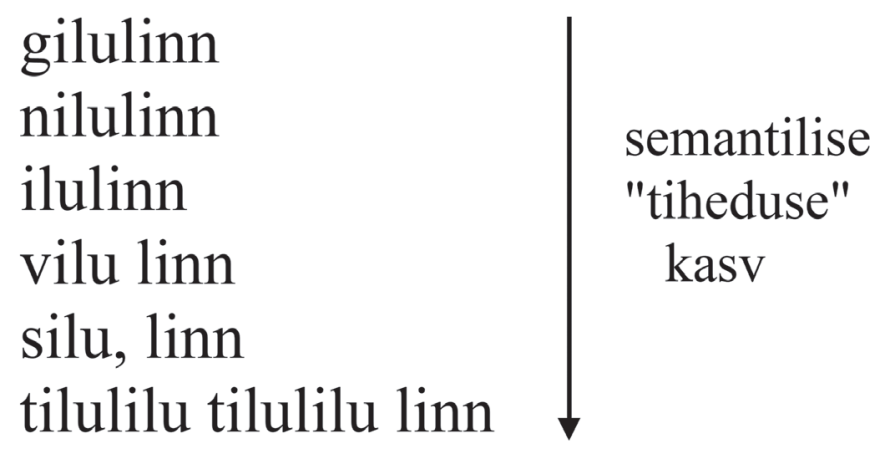

Näide 12. Semantiline "tihendamine" Malini häälutuses "Welcome to Estonia". 


\section{Lõpetuseks}

On kõnekas, et häälutusi ette kandes suhtub Malin teksti sarnaselt klassikalist muusikateost esitava interpreediga. Üsna sageli ehitab ta hääle erinevaid tämbreid kasutades teksti struktuuri kõrvale viimasega dialoogis oleva kõlalise struktuuri, mis suurendab teose aluseks oleva teksti semantilist ambivalentsust veelgi. Kuid analoogiliselt noodikirjale sisaldavad ka Malini tekstid performatiivseid viiteid ja seda hoolimata sellest, et need sarnaselt noodikirjale kogu teose informatsiooni ei kajasta. Nii näiteks viitab suurte algustähtede kasutamine hääle tugevnemisele (muusikateoses vastab sellele dünaamika) või spetsiifilise hääletämbri kasutamisele (vt näidet 5a lõpetavat sõna "ÖÖÖ" või näidet $9 b$ tervikuna). Samuti võivad mitteverbaalsete häälitsuste kasutamisele viidata sõna lõppudes sulgudesse asetatud häälikud, näiteks "töö-tö-tötö-tööö(rr)", milles "rr" tähistab hääliku “ö" üleminekut ebamääraseks urinaks (vt näide 5a).

Erinevalt paljudest kõlalise või rütmilise luulega tegelejatest kasvab Malini häälutuses muusikaline mõõde aga välja keelest (tekstist) ega ole sellele pelgalt lisatud - näiteks räppimisel kipub muusika olema pigem teksti esitamise kontekst, mille olemasolu tagab suuresti näiteks taustal töötav sekventser või rütmimasin. ${ }^{15}$ Nagu eelpool demonstreeriti, viitab Malini häälutuste teksti ülesehitus ühtlasi otseselt muusikaliste arendusvõtete kasutamisele, mis tagavad eelkõige selle kõlalise sidususe ja mida võib mõista teksti muusikalise dimensioonina. Sedalaadi lähenemine võimaldab Malinil esitusliku rütmi tuletada otse tekstist, mis defineerib viimase primaarsena (ja esituse sekundaarsena) ning annab tunnistust Malini kõla- ja vormieksperimentide üllatavalt tihedast seotusest traditsiooniga.

\section{Tänusõnad}

Kirjutise valmimist on toetanud Euroopa Liit Euroopa Regionaalarengu Fondi kaudu (Eesti-uuringute Tippkeskus), see on seotud Eesti Haridus- ja Teadusministeeriumi uurimisprojektiga IUT 12-1. 


\section{Kommentaarid}

1 Ethan Hayden (2012) on kõlaluule tekkimist 20. sajandi alguses vaadelnud eelkõige Jean-Jacques Rousseau filosoofiliste ideede valguses. Teatavasti pidas Rousseau kaasaegset keelt rikutud nähtuseks, mis ei suuda reaalsust adekvaatselt väljendada ega ka kommunikeerida. Rousseau nostalgilised kirjeldused protokeelest, milles ranged keelelised struktuurid väljendust veel ei piira, inspireerisid 20. sajandi alguse futuristidest, sürrealistidest ja dadaistidest poeete, kes püüdsid samuti luua uusi keeli või loobuda keelest kui väljendusvahendist üleüldse. Sellist praktikat õigustas nimetatud poeetide arusaam traditsiooniliselt mõistetud tähendusest kui ratsionaalsesse mõistuse keelde tõlgitud tegelikkusekirjeldusest, mis ei saa olla adekvaatne just oma vahendatuse tõttu. Seepärast oli (liiga otseste ning ratsionaalselt kirjeldatavate) tähenduste tekkimine luules pigem ebasoovitav ning võimalikult otsesele kommunikatsioonile rõhku pannes püüti selliste tähenduste tekkimist vältida. Keelest "pääsemiseks" keskenduti selle "kodustamata" ja tsiviliseerimata äärealadele, milleks võis olla ebatavaline kõnetoon, aga ka karjumine, ulgumine ja tähenduseta "sõnade" kasutamine, ehk kogu väljendusvahendite arsenal, mida kõlaluule kasutab tänapäevani.

2 Absoluutse muusika all peetakse silmas eelkõige arendatud vormidel põhinevat instrumentaalmuusikat, mille puhul on eeldatud, et selle "tähendus" ja "sisu" on põhimõtteliselt konstrueeritavad vaid sellist muusikat moodustavate komponentide ehk selle struktuuri põhjal, s.t laiemast kontekstist sõltumatult. Teoseid, mis end n-ö puhtalt oma struktuuri kaudu kirjeldada lasid, hakati kirjutama juba 18. sajandil, absoluutse muusika mõiste kui teatav ideoloogiline mõiste kujunes aga välja järk-järgult ning kinnistus alles 19. sajandil ja 20. sajandi alguses.

3 Luule kõlalist väljundit on mõningal määral muusikaanalüüsi vahenditega ka käsitletud (vt Lerdahl 2003), kuid mulle teadaolevalt pole traditsioonilise muusikanalüüsi tööriistu kasutatud tekstistruktuuri analüüsimiseks.

${ }^{4}$ William Caplin (s. 1948) on ameerika muusikateoreetik, kelle peateos on "Classical Form: a Theory of Formal Functions for the Music of Haydn, Mozart, and Beethoven".

5 Arnold Schönberg (1874-1951) on austria helilooja ja Uue Viini koolkonna rajaja. Ühtlasi pani ta aluse funktsionaalsele vormiõpetusele, mille olulisemad esindajad peale Schönbergi on Erwin Ratz (1898-1973) ja juba eespool mainitud William Caplin.

6 Peateema koos sellele eelneva motoga moodustab peapartii ehk vormiüksuse, milles valitseb põhihelistik. Beethoveni 5. sümfoonia I osa peapartii hõlmab seega takte $1-21$.

7 Nii nagu takt jaguneb löökideks, millest mõned on rõhulised ja mõned rõhutud, võib ka takte grupeerida suuremateks üksusteks, mille sees mõned taktid on rõhulised ja mõned rõhutud. Selliseid taktigruppe nimetatakse hüpertaktideks ning nende "löökideks" on taktid. Kogu nähtust tervikuna, s.t rütmilise aspekti avaldumist struktuuri kõrgemal tasandil, nimetataksegi hüpermeetrumiks. (Rothstein 1990) Beethoveni 5. sümfoonia I osa peateema puhul võib seega rääkida kahest neljalöögilisest hüpertaktist (taktid 7-19 ja 11-14), millele järgneb kaks kahe- ja kaks ühelöögilist hüpertakti (vastavalt taktid 15-16 ja 17-18 ning 19 ja 20). Siit tuleneb, et killustamist või muusikalise materjali tihendamist võib käsitleda ka protsessina, milles hüpertakti pikkus läheneb järk-järgult reaalse takti pikkusele. 
${ }^{8}$ Fermaat ehk peatus on muusikas üks noodivältuse pikendamise vahendeid. Erinevalt teistest vältuse pikendamise vahenditest ei ole fermaadi väärtus (s.t see, kui palju see nooti konkreetselt pikendab) üheselt määratletud ning sõltub suuresti esitusest.

9 Klassikalises muusikas võib muusikaline lause lõppeda tavaliselt kas täis- või poolkadentsiga. Esimesel juhul lõpeb kadents toonika ehk I astme harmooniaga, teisel puhul aga dominandi ehk V astme harmooniaga. Erinevalt täiskadentsist loob poolkadents oma lahtisuse või lõpetamatuse tõttu (V astme harmoonia on enamasti ebapüsivam kui I astme harmoonia) vajaduse muusikalise protsessi jätkumiseks, mistõttu seda kasutatakse teosesiseste lausete lõpetamiseks. Teost tervikuna lõpetav kadents peab klassikalises muusikas olema alati täiskadents.

${ }^{10}$ Ilmar Laaban (1921-2000) on eesti luuletaja, tõlkija ja publitsist.

${ }^{11}$ Mõeldud on Ilmar Laabani luulekogu "Ankruketi lõpp on laulu algus”, mis ilmus 1946. aastal Stockholmis.

12 Jaan Malin (1960) on eesti luuletaja ja kultuuriürituste korraldaja.

${ }^{13}$ Klassikalises muusikas saab muusikaliseks heliks olla ainult perioodilisel võnkumisel põhinev ehk mingi kindla kõrgusega heli ning kõik muu on klassifitseeritav müraks.

14 Vt näiteks Perloff (2009).

${ }^{15}$ Siin ei väideta, nagu oleksid Malini häälutused esmalt sündinud kui keelelised ideed, millele hiljem on antud kõlaline vorm. Usutavam on pigem vastupidine, mille puhul kõlaline idee genereerib keelelise struktuuri (umbes nii, nagu muusikas tuletatakse kõlalisest ideest teose struktuur). Kuid kui nimetatud struktuur on moodustunud, muutub see ka Malinil analoogiliselt klassikalise muusika nooditekstiga aluseks, mille pinnalt esituslikud otsused tehakse.

\section{Allikad}

Malin, Jaan. Hä̈̈lutuste käsikirju. Autori omand.

Malin, Jaan. Jaan Malin@T-junction. You-tube video; https://www.youtube.com/ watch?v=w9sXdn5_KKA (14. november 2017).

\section{Kirjandus}

Caplin, William 1998. Classical Form: a Theory of Formal Functions for the Music of Haydn, Mozart, and Beethoven. New York: Oxford University Press.

Hayden, Ethan 2012. Adamic passions, screams of joy: Language and expression in early 20th-century sound poetry. Mosaic: Journal Of Music Research 2 (http://www. ethanhayden.com/writing/publications/Hayden-AdamicPassions.pdf - 15. november 2017).

Lerdahl, Fred 2003. The Sounds of Poetry Viewed as Music. Peretz, Isabelle \& Zatorre, Robert J (toim). The Cognitive Neuroscience in Music. Collection of Essays. New York: Oxford University Press, lk 413-429 (doi: 10.1111/j.1749-6632.2001.tb05743.x). 
Muru, Karl 2000. Ilmar Laaban. Kruus, Oskar \& Puhvel, Heino (koost). Eesti kirjanike leksikon. Tallinn: Eesti Raamat, lk 261-262.

Perloff, Nancy 2009. Sound poetry and the musical avant-garde: A musicologist's perspective. Perloff, Marjorie \& Dworkin, Craig (toim). The sound of poetry / The poetry of sound. Chicago: University of Chicago Press, lk 97-117 (doi: 10.7208/ chicago/9780226657448.003.0009).

Rothstein, William 1990. Phrase Rhythm in Tonal Music. New York: Schirmer Books.

\title{
Summary
}

\section{On techniques of musical development and construction of musical dimension in the sound poetry of Jaan Malin}

\author{
Kerri Kotta \\ Professor of music theory \\ Estonian Academy of Music and Theatre \\ kerri.kotta@gmail.com
}

Keywords: language, musical form, sound poetry, techniques of musical development

Sound poetry is an artistic form in which phonetic qualities are usually given preference over the semantic content. In sound poetry, it is especially the rhythm and sound (timbre) of words which is used to build up meaningful structures. Due to this feature, sound poetry resembles the so-called absolute music, i.e., classical instrumental music based on extended and complex forms. In the absolute music, the unfolding of a work's musical form is simultaneously understood as its content (hence the idea of formal aesthetics that the way of saying is, in a sense, equivalent to what is being said). This is why the analysis of form plays such an important role in the classical music. This article suggests the idea that the tools used in the analysis of formal structures of classical instrumental music can be applied also to sound poetry to uncover its content and meaning.

The article concentrates on the sound poetry of Estonian poet and writer Jaan Malin. Malin's interest in sound poetry was awakened by another Estonian poet Ilmar Laaban, whose works Malin saw as examples. In his works, Malin uses several techniques to achieve timbral continuity of the text, including repetition, fragmentation, and liquidation, timbral "links", timbral palindromes or retrogrades, transformation of the sound of words, and formal overlaps and interpolations. Occasionally Malin applies metrical structures characterising also the main theme, i.e., the entire musical phrase or group of phrases of a musical work.

In Malin's works, the repetition usually displays a word or a group of words followed by a number of its timbral equivalents, i.e., the words or sound forms (new words invented by the poet having no concrete meaning) that include the same number of syllables, but which are slightly different from the original form. Sometimes longer words 
or word groups are gradually replaced by shorter words, which creates intensification. Such a phenomenon is referred to as fragmentation in this study. In specific contexts, the fragmentation can be followed by an opposite phenomenon - the summation (shorter words are followed by longer words), which in the analysis of a musical sentence is usually referred to as liquidation.

To connect larger formal units, Malin sometimes uses "links", i.e., the words or wordlike fragments having similar sound. The "links" can be direct or indirect. In creating a new "link", a word is followed by another word that displays the same vowels in the same or reverse order. The first corresponds to the direct, and the second to the indirect "link" accordingly. The latter is also referred to as timbral palindrome or retrograde in this study. Sometimes, there is also a gradual transition from one formal section to another. Such transitions are described as transformations since the dominating words of a new formal section appear as a result of a continuous elaboration of words governing the preceding section.

The shortest and simplest way to link two sections is to use a word that functions simultaneously as the last word of the preceding and the first word of a new section. Analogous to music, such a link is referred to as overlap. In addition, Malin in his works occasionally takes the position of a commentator, expressing his opinion on the text. This creates a kind of narrative caesura, interruption of continuity, which can be paralleled with that of interpolation in music analysis.

Malin does not use the techniques of musical development for their own sake. Rather, he uses these to enter the dimension of music as he uses the semantic content of words to return to the dimension of language. From the perspective of language, switching between the two dimensions can also be understood as semantic "release" or "recharge" accordingly. 